\title{
Carbon C14 EGFR Inhibitor ASP8273
}

National Cancer Institute

\section{Source}

National Cancer Institute. Carbon C14 EGFR Inhibitor ASP8273. NCI Thesaurus. Code C131288.

A radioconjug ate composed of ASP8273, an orally available, third-generation, mutantselective, irreversible epidermal growth factor receptor (EGFR) inhibitor, labeled with the radioisotope carbon C 14, with potential use for evaluating the pharmacokinetic profile of ASP8273 during positron emission tomography (PET). Upon administration of carbon C 14 ASP8273, ASP8273 targets, covalently binds to and inhibits the activity of mutant forms of EGFR, including the T790M mutant form. Labeling of ASP8273 with the radioactive tracer carbon C 14 permits the evaluation of this agent's pharmacokinetic profile, including its absorption, distribution, metabolism, and excretion (ADME) using PET. 